\title{
Effect of Macrophomina phaseolina on growth and expression of defense related genes in Arabidopsis thaliana
}

\author{
Shehzadi Saima ${ }^{1,2^{*}}$ and Guang $\mathrm{Wu}^{1}$ \\ ${ }^{I}$ College of Life Science, Shaanxi Normal University, Xi'an, Shaanxi Province, 710119 P.R. China. \\ ${ }^{2}$ Institute of Pure and Applied Biology, Bahauddin Zakariya University Multan, Pakistan.
}

Submitted: 12 September 2017; Revised: 12 May 2018; Accepted: 22 June 2018

\begin{abstract}
Infection caused by the necrotrophic fungal pathogen Macrophomina phaseolina leads to changes in the growth, development, and metabolism in plants. Plants produce defense responses as a result of infection. The present study was designed to evaluate the defense responses in the model plant Arabidopsis thaliana inoculated with M. phaseolina. Reduction in shoot length, root length, photosynthetic pigments, relative water content (RWC) and increase in sugar and proline contents in leaves were recorded as defense responses in the inoculated plants. Analysis of gene expression showed that among defense related genes, the expression of mitogen-activated protein kinases and thaumatin proteins increased while chitinase and beta-1,3-glucanase showed little increase compared with control plants. It is, therefore, concluded that defense related genes along with increased sugar and proline may play a role in the development of resistance against M. phaseolina.
\end{abstract}

Keywords: Arabidopsis thaliana, gene expression, Macrophomina phaseolina, necrotrophic fungus, pathogenesis related proteins.

\section{INTRODUCTION}

Macrophomina phaseolina is a globally distributed necrotrophic fungal pathogen which belongs to the class Deuteromycetes. It can cause infection in more than 500 plant species of more than 100 families including economically important crops such as maize, $\operatorname{sorghum}(\mathrm{Su}$ et al., 2001), common bean (Mayek-Perez et al., 2001), gram (Raguchander et al., 1993), cotton (Aly et al., 2007), sunflower (Khan, 2007) and groundnut (Sobti \& Sharma, 1992). The disease is named as charcoal rot, root rot, stem rot, seedling damping-off, seedling blight ashy or stem blight depending on the plant species and the part it infects. M. phaseolina infects plants at almost all growth stages. Diseases caused by M. phaseolina become more severe under high temperature and in dry environments and can severely reduce the yield (Bashir \& Malik, 1988). It is very difficult to control this fungus because it can remain viable in soil and plant debris for many years as sclerotia (Short \& Wyllie, 1980). M. phaseolina is distributed globally from tropical to subtropical and arid to semi-arid regions of Asia, Africa, Europe and America (Wrather et al., 2001). Despite having a wide geographical distribution and broad host range, Macrophomina is a monotypic genus (Purkayastha et al., 2006).

Fungal pathogen invasion interferes with several physiological processes such as reduction in the growth of plants, alterations in total chlorophyll content (chlorophyll a and b) and reduction in photosynthesis which consequently decreases biomass (Pazarlar et al., 2013). Proline is a kind of protein that confers tolerance to plants against pathogens (Qamar et al., 2015).

In response to pathogen infection, plants also start producing pathogenesis-related (PR) proteins because they are important weaponry of the whole plant against the pathogen and have the ability to inhibit fungal growth (Ebrahim et al., 2011). PR proteins are evolutionarily conserved in the plant kingdom and broadly classified into 17 families based on their biochemical functions

\footnotetext{
*Corresponding author (shehzadi.saima@bzu.edu.pk; (DD https://orcid.org/0000-0001-9511-0293)
} 
and sequence similarity. These include chitinases (Cletus et al., 2013), glucanases (Singh et al., 2014), thaumatinlike proteins (Acharya et al., 2013), mitogen-activated protein kinases (Beckers et al., 2009) and osmotin-like proteins (Subramanyam et al., 2012). Chitinases are the enzymes that hydrolyse the main structural components of the fungus cell wall and release the cell wall elicitors of defense reactions (Souza et al., 2017). Arabidopsis thaliana has about 25 open reading frames that have chitinase or chitinase-like sequences. The average length of these chitinases in A. thaliana is 308 amino acids (Akenaka et al., 2009). These chitinases also have been involved in other plant physiological processes such as growth and development, programmed cell death and resistance to different environmental stresses (Grover, 2012). Therefore, chitinases are very important genes for increasing biotic stress resistance in plants. Another PR protein is $\beta$-1,3-glucanase, also referred as PR2, which hydrolyses $\beta$-1,3-linked glucans (non-starch polysaccharide), a structural component of fungal cell walls. It indirectly releases the elicitors that initiate a chain of reactions by reducing hydrolysis of fungal cell walls (Moravcikova et al., 2016).

In Arabidopsis, a defense response against pathogens also includes the activation of the mitogen-activated protein kinase (MPK) cascade (Eschen-Lippold et al., 2012). Those are mainly involved in the stress responses and activated by both biotic and abiotic stresses (Alzwiya $\&$ Morris, 2007). Thaumatin-like proteins (TLPs) showed great sequence homology with PR-5 proteins that are activated in plants upon fungal infection (Ahmed et al., 2013). TLPs have the ability to rupture the fungal membrane by forming a pore and inhibiting further spread (Roberts \& Selitrennikoff, 1990). In A. thaliana, these TLPs showed antifungal activity against Verticillium alboatrum, V. dahliae and Fusarium oxysporum (Hu \& Reddy, 1997). Osmotin is also a stress responsive, multifunctional basic protein. These proteins show antifungal activity by permeabilising the fungal plasma membrane and resulting in dissipation of the membrane potential of the fungi (Subramanyam et al., 2012).

Not much research has been conducted to determine the effects of $M$. phaseolina on defense responses of A. thaliana. The main objective of the current study was to evaluate the role of physiological parameters (chlorophyll, sugar, protein and proline contents) and major defense related genes in the defense response of the model plant $A$. thaliana in the presence of M. phaseolina.

\section{METHODOLOGY}

\section{Collection of fungus}

The strain of fungus (Macrophomina phaseolina) used in this research project was obtained from the National Agricultural Research Council (NARC), Islamabad, Pakistan.

\section{Systemic inoculation of the fungus}

\section{Preparation of fungal inoculum on Sorghum seeds}

Sorghum seeds were sterilised with ethanol (70\%) and then washed with distilled water thrice and soaked overnight in distilled water. Seeds were dried and autoclaved. The autoclaved seeds $(100 \mathrm{~g})$ were placed in each $500 \mathrm{~mL}$ flask and inoculated with one $4 \mathrm{~mm}$ diameter mycelial disk per flask with the help of a cork-borer. The seeds were mixed and the flasks were placed in an Isotemp Standard Lab Incubator (Thermo Fisher Scientific ${ }^{\circledR}$, USA) at $30-32{ }^{\circ} \mathrm{C}$ for 15 ds. Flasks were shaken every day. After $15 \mathrm{ds}$, maximum spore concentration was obtained and fungal mycelial growth could be observed with the naked eye. Two grams of inoculated sorghum seeds were mixed with $1 \mathrm{~kg}$ of peat soil. The seed-inoculated soil was used for sowing Arabidopsis seeds.

\section{Plant material and growth conditions}

Seeds of Col-0 ecotype plants of $A$. thaliana were obtained from the National Agricultural Research Council (NARC), Islamabad, Pakistan in 2016. Seeds were surface sterilised with sodium hypochlorite $(\mathrm{NaClO})$ for $5 \mathrm{~min}$ and washed with distilled water thrice. The seeds were sown in Petri dishes containing half strength MS Murashige and Skoog medium (Murashige \& Skoog, 1962). For stratification, the Petri dishes were placed at $4{ }^{\circ} \mathrm{C}$ in darkness for $3 \mathrm{ds}$ and transferred to a controlled climate greenhouse (with $9 / 15 \mathrm{~h} \mathrm{light/dark}$ cycle, $22{ }^{\circ} \mathrm{C}$ and $2001 \mathrm{~mol} \mathrm{~m}^{-2} \mathrm{~s}^{-1}$ light intensity). After $2 \mathrm{wks}$, half of the young seedlings were transplanted into $600 \mathrm{~mL}$ plastic pots. Three seedlings were transferred to each pot containing garden peat soil and these plants were used as the control. The remaining half were transplanted to the soil containing fungal inoculum. Both control and treated plants were kept in a greenhouse with the above mentioned conditions. Plants were irrigated with water weekly up to saturation of soil. 


\section{Harvesting}

Both treated and control plants were harvested four weeks after germination for expression profiling of defense related genes. Plants were frozen in liquid nitrogen immediately after harvest and stored at $-80^{\circ} \mathrm{C}$.

\section{Determination of physiological and biochemical parameters}

\section{Sugar content of leaves}

By following the procedure described by Dubo et al. (1956) and amended by Johnson et al. (1966), total sugar content of the leaves of treated and control plants were measured. In this assay, $0.5 \mathrm{~g}$ of one month old fresh leaves were homogenised by adding $10 \mathrm{~mL}$ of distilled water and then centrifuged for $5 \mathrm{~min}$ at $3000 \mathrm{rpm}$. The supernatant $(0.1 \mathrm{~mL})$ was mixed with $1 \mathrm{~mL}$ of phenol ( $80 \%)$ and the mixture was incubated at room temperature for $1 \mathrm{~h}$. Concentrated sulphuric acid $\left(\mathrm{H}_{2} \mathrm{SO}_{4}\right)$ was added to the mixture and incubated at room temperature for $4 \mathrm{~h}$ and the absorbance was measured at $420 \mathrm{~nm}$ in a spectrophotometer (Bio-Tek Instruments Inc. USA), using water as blank. By using the standard curve, sugar content of unknown samples was calculated in three replicates.

\section{Protein content}

Leaves were harvested for the determination of protein content by following the method of Lowry et al. (1951). Protein extraction was done in phosphate buffer. For the preparation of phosphate buffer, $2.76 \mathrm{~g}$ of dibasic sodium phosphate was dissolved in $100 \mathrm{~mL}$ distilled water. Monobasic $(16 \mathrm{~mL})$ and dibasic $(84 \mathrm{~mL})$ sodium phosphate were mixed and the $\mathrm{pH}$ was adjusted to 7.5. For protein extraction, $0.1 \mathrm{~g}$ of leaves was taken and homogenised with $1 \mathrm{~mL}$ phosphate buffer with the help of mortar and pestle. The mixture was centrifuged at $3000 \mathrm{rpm}$ for $10 \mathrm{~min}$. The supernatant $(0.1 \mathrm{~mL})$ was taken in a test tube and $0.9 \mathrm{~mL}$ distilled water was added to make a total volume of $1 \mathrm{~mL}$. Other reagents were prepared as follows;

Reagent A: $2 \mathrm{~g}$ of sodium carbonate $\left(\mathrm{Na}_{2} \mathrm{CO}_{3}\right), 0.4 \mathrm{~g}$ of $\mathrm{NaOH}$ and $1 \mathrm{~g}$ of N-K tartarate dissolved in $100 \mathrm{~mL}$ of water.

Reagent B: $\mathrm{CuSO}_{4} \cdot 5 \mathrm{H}_{2} \mathrm{O}(0.5 \mathrm{~g})$ was dissolved in $100 \mathrm{~mL}$ of distilled water.

Reagent C: Reagent A $(50 \mathrm{~mL})$ and reagent B $(1 \mathrm{~mL})$ were mixed together.

$50 \%$ folin phenol reagent was named as reagent $\mathrm{D}$.
One milliliter of reagent $\mathrm{C}$ was shaken for $10 \mathrm{~min}$ and then $0.1 \mathrm{~mL}$ of reagent $\mathrm{D}$ was added. The mixture was incubated at room temperature for $30 \mathrm{~min}$. The absorbance of each sample was recorded at $650 \mathrm{~nm}$. Buffer was used as the blank. Protein contents of leaves were determined by the following formula;

Protein content $=\frac{\mathrm{k} \times \text { Absorbance } \times \text { dilution factor }}{\text { sample weight }}$

\section{Proline content of leaves}

The procedure of Bates et al. (1973) was used for the measurement of proline content of the leaves. In this method fresh leaves of $0.1-0.2 \mathrm{~g}$ were homogenised with $4 \mathrm{~mL}$ of $3 \%$ sulfosalicylic acid using mortar and pestle. The mixture was centrifuged for $5 \mathrm{~min}$ at $2000 \mathrm{rpm}$, supernatant $(2 \mathrm{~mL})$ was collected and $2 \mathrm{~mL}$ of ninhydrin solution was added. The ninhydrin solution was prepared by adding $1.25 \mathrm{~g}$ of ninhydrin into a mixture of $30 \mathrm{~mL}$ of glacial acetic acid and $20 \mathrm{~mL}$ of $6 \mathrm{M}$ phosphoric acid. The mixture was incubated at $100{ }^{\circ} \mathrm{C}$ in a water bath for $1 \mathrm{~h}$. Then $4 \mathrm{~mL}$ of toluene was added and shaken for 15-20 s. From the aqueous phase, toluene was aspirated. Toluene was used as the standard and absorbance was recorded at $530 \mathrm{~nm}$. From the standard curve, proline concentration of all samples were determined.

\section{Chlorophyll content}

Chlorophyll content of leaves was determined by the method described by Arnon (1949). Fresh leaves $(0.3 \mathrm{~g})$ were ground using mortar and pestle with $5 \mathrm{~mL}$ of $80 \%$ acetone. The mixture was centrifuged at $3000 \mathrm{rpm}$ for $12 \mathrm{~min}$ and the supernatant was collected. The absorbance of supernatant was measured at $650 \mathrm{~nm}$. Acetone (80\%) was used as the blank for all measurements. To calculate milligrams of chlorophyll per gram fresh weight, the following formula described by Arnon (1949) was used;

Total chlorophyll $\mathrm{mgmL}^{-1}=\mathrm{A} 650 / 34.5$

\section{Shoot and root length}

Using a measuring tape, length of the freshly harvested shoots and roots were measured in three replicates.

\section{Relative water content of leaves}

Relative water content (RWC) of leaves was determined by following the method described by Weatherly (1950) and using the following formula; 
$\mathrm{RWC} \%=(\mathrm{FW}-\mathrm{DW}) /(\mathrm{FT}-\mathrm{DW}) \times 100$

where $\mathrm{FW}=$ fresh weight, $\mathrm{DW}=$ dry weight, $\mathrm{FT}=$ fresh turgid weight

\section{$R N A$ extraction, quantification and $c D N A$ synthesis}

In order to study the expression level of six PR genes (Table 1), RNA was extracted from the control and inoculated plants. RNA extraction was done by Gene JET plant RNA purification kit (Thermo scientific ${ }^{\circledR}$ Qiagen, Germany) by using $0.5 \mathrm{~g}$ of fresh leaves. The mRNA concentration was estimated by spectrophotometer (Bio-Tek Instruments Inc. USA).
M-MLV, a reverse transcriptase (Invitrogen, Life Technologies) was used to synthesise first-strand cDNA according to manufacturer's instruction. The cDNA was stored at $-20{ }^{\circ} \mathrm{C}$ until further use.

\section{Primer designing, PCR and RT-PCR}

Real time PCR (RT-PCR) was performed to check the expression of six defense related genes. Total cDNA was used as a template and respective genes were amplified using specific primers (Table 1). Primers were designed by using Oligo 6. To standardise cDNA samples of each PCR, actin was used as an internal control.

Table 1: Real-time PCR primer sequences used for amplification of different PR genes

\begin{tabular}{|c|c|c|c|c|}
\hline Gene name & Accession No. & Forward primer & Reverse primer & $\begin{array}{l}\text { Product } \\
\text { size (bp) }\end{array}$ \\
\hline Chitinase $(\mathrm{CH})$ & NM_122314.3 & 'CCAAAACGGAAACGAAGGTA' & 'AACCTTGATGCCACGAGACT' & 199 \\
\hline Beta-1,3-glucanase (GLU) & NM_123575.4 & 'AACATGAAGCCTGGACCAAC' & 'GTTACCCGTGACTGGCTGAT' & 210 \\
\hline EDR1 & NM_100745.2 & 'AATCGGATTCACGTTTCTGC' & 'GCTCGGATCTGATGCTTCTC' & 230 \\
\hline $\begin{array}{l}\text { Mitogen-activated } \\
\text { protein kinase } 4 \text { (MPK4) }\end{array}$ & NM_116367.3 & 'GCATGGTTTGAGCTGATGAA' & 'TGGGGATTCTTTGATCTTCG' & 177 \\
\hline Osmotin (OSM) & NM_117234.3 & 'ACGGTCAGGGATCATGTAGC' & 'CACCCTCACACACACACACA' & 245 \\
\hline Thaumatin (TH) & NM_106230.4 & 'TCCAATTCAATGGCTCTTCC' & 'CAGAATCTTCCTCCCCATGA' & 230 \\
\hline Actin (ACT2) & NM_001338358.1 & 'TGCCAATCTACGAGGGTTTC' & 'TTCTCGATGGAAGAGCTGGT' & 226 \\
\hline
\end{tabular}

\section{Real-time PCR analysis}

Applied Biosystems 7300 real-time PCR system (Thermo Fisher Scientific ${ }^{\circledR}$, USA) was used to perform quantitative real time PCR. For qPCR, $3 \mu \mathrm{l}$ of cDNA and $5 \mu \mathrm{L}$ of SYBR Green PCR Master Mix (Thermo Fisher Scientific $\AA$, USA) was used for thermal cycling with the following conditions: initial denaturation at $95{ }^{\circ} \mathrm{C}$ for $1 \mathrm{~min}, 40$ cycles of $95{ }^{\circ} \mathrm{C}$ for $15 \mathrm{~s}, 54{ }^{\circ} \mathrm{C}$ for $15 \mathrm{~s}$, and $72{ }^{\circ} \mathrm{C}$ for $45 \mathrm{~s}$ and final extension at $72{ }^{\circ} \mathrm{C}$ for $10 \mathrm{~min}$. Actin was used as housekeeping gene (Pathan et al., 2017). This experiment was repeated thrice.

\section{Statistical analysis}

The experiment was carried out with three replicates unless otherwise stated (represented with $\mathrm{n}$ value). The data were subjected to one-way analysis of variance (ANOVA), using STATISTICA (version 5.5 a) at 0.05 level of significance.

\section{RESULTS AND DISCUSSION}

Plants are sessile organisms, therefore they have evolved self-defense systems to protect themselves against different environmental stresses. Interactions between plants and fungal pathogens involve alterations in physiological and biochemical parameters as well as induction of genes that confer resistance to plants.

\section{Growth parameters}

When pathogens infect a plant, they interfere with physiological functions of the plant that result in the appearance of different symptoms (Pazarlar et al., 2013). In this study infection of $M$. phaseolina resulted in significant reduction in the growth parameters such as shoot length, root length, and relative water content in A. thaliana. Infected plants showed deleterious effects on the overall growth of the plants (Table 2) as indicated by Eastburn et al. (2011). 
Table 2: Effect of inoculation of M. phaseolina on shoot length, root length, relative water content and chlorophyll content of 4 -week-old seedlings of $A$. thaliana seedlings. Values represent mean $\pm \mathrm{SEM}$ of 3 replicates. Means sharing different letters in a column are significant at $\mathrm{p}<0.05$.

\begin{tabular}{lcccc}
\hline Treatments & $\begin{array}{c}\text { Shoot length } \\
(\mathrm{m})\end{array}$ & $\begin{array}{c}\text { Root length } \\
(\mathrm{m})\end{array}$ & $\begin{array}{c}\text { Relative water content } \\
(\%)\end{array}$ & $\begin{array}{r}\text { Chlorophyll content } \\
(\mathrm{mg} / \mathrm{g} \text { fresh matter })\end{array}$ \\
\hline Control & $18.2^{\mathrm{a}} \pm 1.3$ & $2.5^{\mathrm{a}} \pm 0.3$ & $86^{\mathrm{a}} \pm 6.2$ & $1.1^{\mathrm{a}} \pm 0.11$ \\
Inoculated & $15.7^{\mathrm{b}} \pm 0.9$ & $1.7^{\mathrm{b}} \pm 0.2$ & $57^{\mathrm{b}} \pm 5.6$ & $1.57^{\mathrm{ab}} \pm 0.18$ \\
\hline
\end{tabular}

\section{Sugar content}

Pathogen infection is one of the drastic environmental stresses that plants face. As a result of this stress, a series of reactions activate to enhance the defense. To accomplish these defense responses, energy is required due to up- and down-regulation of several genes from multiple defense pathways (Scheideler et al., 2002). Energy can be derived from different metabolic activities, i.e. by increasing the respiratory metabolism. In many plant species, sucrose is the main transport sugar. In $A$. thaliana tolerance to biotic stress is strongly enhanced by the accumulation of sucrose (Verslues \& Sharma, 2010). The results of the present study were consistent with the findings that total sugar contents were higher in inoculated seedlings compared to the control (Morkunas \& Ratajczak, 2014). However, the increase was not statistically significant (Table 3).
Increased sugar content is one of the adaptive strategies of plants for the maintenance of structure and functions during biotic stress (Hirabayashi, 1996).

\section{Protein and proline content}

The results presented in Table 3 show that Arabidopsis plants subjected to $M$. phaseolina infection have increased the protein and proline contents in leaves as compared to the control. Protein content of inoculated leaves showed $43 \%$ increase as compared to the control. Inoculated Arabidopsis leaves had $71 \%$ increase in proline content than that of the control (Table 3). When higher plants are under stress they accumulate greater amounts of proline (Pazarlar et al., 2013). As a result reactive oxygen species (ROS) are produced causing programmed cell death around the point of infection and terminate the disease progress (Qamar et al., 2015).

Table 3: Effect of inoculation of M. phaseolina on sugar content, protein content, and proline content of leaves of 4-week-old seedlings of $A$. thaliana. Values represent mean \pm SEM of 3 replicates. Means sharing different letters in a row or in a column are significant at $\mathrm{p}<0.05$.

\begin{tabular}{lccc}
\hline Treatments & $\begin{array}{c}\text { Sugar content } \\
(\mu \mathrm{g} / \mathrm{g} \text { fresh weight })\end{array}$ & $\begin{array}{c}\text { Protein content } \\
(\mu \mathrm{g} / \mathrm{g} \text { fresh weight })\end{array}$ & $\begin{array}{c}\text { Proline content } \\
(\mu \mathrm{g} / \mathrm{g} \text { fresh weight })\end{array}$ \\
\hline Control & $121^{\mathrm{a}} \pm 5.1$ & $203^{\mathrm{a}} \pm 10.3$ & $557^{\mathrm{a}} \pm 25.1$ \\
Inoculated & $225^{\mathrm{ab}} \pm 11.2$ & $251^{\mathrm{b}} \pm 12.5$ & $697^{\mathrm{b}} \pm 31.7$ \\
\hline
\end{tabular}

\section{Chlorophyll content}

Fungal infection damages the ultra-structure of chloroplasts that affect chlorophyll pigments $\mathrm{a}$ and $\mathrm{b}$ and hence reduces the rate of photosynthesis (Lobato et al., 2009). The results suggest that plants subjected to M. phaseolina infection exhibited significantly lower chlorophyll content as compared to the control (Table 2).

\section{Gene expression}

Chitinase is a hydrolytic enzyme that belongs to the parthenogenesis-related (PR) protein family and plays a crucial role in defense against biotic stress. During infection, chitinase enzyme degrades the chitins in the cell walls of fungi and inhibits the growth of the pathogen (Sela-Buurlage et al., 1993; Jayaraj \& Punja, 2007). In 
the present investigation transcript level of chitinase gene was up-regulated as a response to M. phaseolina infection (Figure 1). Grover (2012) and Cletus et al.
(2013) also reported the up-regulation of chitinase gene in plants as a defense mechanism under fungal infection.

Table 4: Analysis of variance (ANOVA) of shoot length, root length, relative water content, chlorophyll content, sugar content, protein content and proline content of 4-week-old seedlings of A. thaliana inoculated with M. phaseolina

\begin{tabular}{lccccccc}
\hline Source & Shoot length & Root length & $\begin{array}{c}\text { Relative water } \\
\text { content }\end{array}$ & $\begin{array}{c}\text { Chlorophyll } \\
\text { content }\end{array}$ & $\begin{array}{c}\text { Sugar content } \\
(\mu \mathrm{g} / \mathrm{g} \text { fresh } \\
\text { weight })\end{array}$ & $\begin{array}{c}\text { Protein content } \\
(\mu \mathrm{g} / \mathrm{g} \text { fresh } \\
\text { weight })\end{array}$ & $\begin{array}{c}\text { Proline content } \\
(\mu \mathrm{g} / \mathrm{g} \text { fresh } \\
\text { weight })\end{array}$ \\
\hline Treatment & $1811.3^{* * *}$ & $1309.64 * * *$ & $1954.29 * * *$ & $3737.39 * * *$ & $899.01 \mathrm{~ns}$ & $1497.5 * * *$ & $2367.5 * * *$ \\
\hline
\end{tabular}

$*=$ significant $(\mathrm{p}<0.05) ; * *=$ significant $(\mathrm{p}<0.01) ; * * *=$ highly significant $(\mathrm{p}<0.00) ; \mathrm{F}$ values are given; ns $=$ not significant

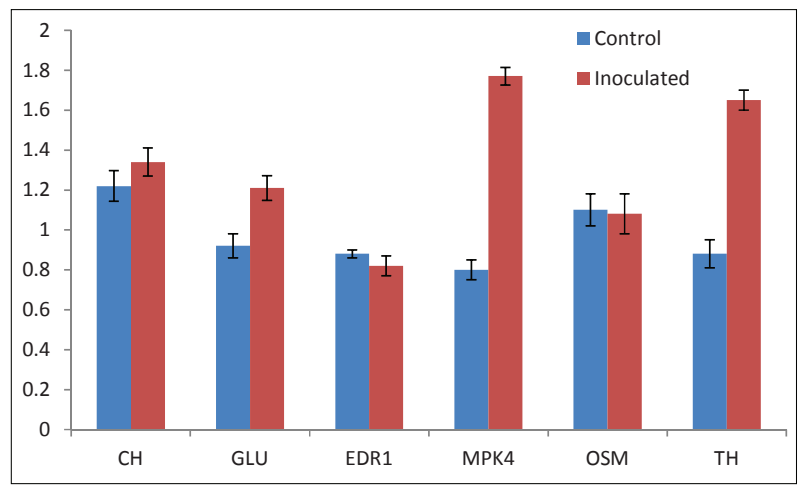

Figure 1: Relative expression of PR gene transcripts in A. thaliana plants infected by M. phaseolina and non-infected control plants. The data was obtained from real-time RT-PCR analysis. Bars represent means \pm standard deviations of five replications. Abbreviations- $\mathrm{CH}$ : chitinase; GLU: beta-1,3-glucanase; EDR1: enhanced disease resistance 1; MPK4: Mitogen-activated protein kinase 4; OSM: osmotin; TH: thaumatin

$\beta$-1,3-glucanase is a well-known pathogenesis-related protein and induction of this protein is mostly associated with the induction of chitinase during biotic stresses (Liu et al., 2010). In the present study expression of $\beta$-1,3-glucanase was highly stimulated in Arabidopsis after inoculation with $M$. phaseolina compared to uninoculated controls (Figure 1). This suggests that the up -regulation of this gene may play an important role in plant defense. $\beta$-1,3-glucanase can degrade the cell wall of the pathogen or release the oligosaccharide elicitors to induce defense reactions and both of these mechanisms are very effective against fungal infections. Therefore $\beta$-1,3-glucanase play an important role in plant defense because the cell wall of an organism is the protective barrier against infection mechanisms and survival of the organism depends on its integrity (Moravcikova et al., 2016).

Treatment of plants with microorganisms leads to changes in the phosphorylation of proteins. Among protein kinases, the MPK family is very important and MPKs have been associated with various stress responses, especially in pathogenesis. The present study showed that in A. thaliana, MPK4 was activated in the plants infected by M. phaseolina. The strong upregulation of this gene in the infected plants enhanced the resistance in Arabidopsis against the fungal infection (Beckers et al., 2009).

Osmotin is an antifungal protein that has a broad spectrum of antifungal activities. It recognises the target site by interaction with the pathogen cell surface that has glycoproteins or phosphomannan components that either enhance or reduce the fungal activity (Subramanyam et al., 2012). In the present study, the expression level of osmotin and enhanced disease resistance 1 (EDR1) was down-regulated in the inoculated plants as compared to normal plants although this down-regulation was not significant (Figure 1). Similar results were reported by Parkhi et al. (2009).

Thaumatin proteins also have a contributory role in increasing the tolerance against both biotic and abiotic stresses (El-kereamy et al., 2011). In this study inoculated plants showed resistance to $M$. phaseolina infection due to high induction of thaumatin. This gene was upregulated almost double as compared to un-inoculated control plants (Figure 1). Similar results were presented by Hu and Reddy (1997) and Ahmed et al. (2013). 


\section{CONCLUSION}

Arabidospsis thaliana was found susceptible and responded to the infection of Macrophomina phaseolina by stimulating the accumulation of different defense related compounds like sugar, proline, chlorophyll and total protein in the cell. Among defense related genes, the expression of MPK4 and thaumatin was the highest.

\section{REFERENCES}

Acharya K., Pal A.K., Gulati A., Kumar S., Singh A.K. \& Ahuja P.S. (2013). Over expression of Camellia sinensis thaumatin-like protein, CsTLP in potato confers enhanced resistance to Macrophomina phaseolina and Phytophthora infestans infection. Molecular Biotechnology 54: 609-622. DOI: https://doi.org/10.1007/s12033-012-9603-y

Ahmed N., Kang K.K., Lim Y.P. \& Nou I.S. (2013). Molecular characterization of thaumatin family genes related to stresses in Brassica rapa. Scientia Horticulturae 152: 26-34.

DOI: https://doi.org/10.1016/j.scienta.2013.01.007

Akenaka Y.T., Nakano S., Tamoi M., Sakuda S. \& Fukamizo T. (2009). Chitinase gene expression in response to environmental stresses in Arabidopsis thaliana: chitinase inhibitor allosamidin enhances stress tolerance. Bioscience Biotechnology Biochemistry 73(5): 1066-1071. DOI: https://doi.org/10.1271/bbb.80837

Aly A.A., Abdel-Sattar M.A., Omar M.R. \& Abd-Elsalam K.A. (2007). Differential antagonism of Trichoderma sp. against Macrophomina phaseolina. Journal of Plant Protection Research 47: 91-102.

Alzwiya I.A. \& Morris P.C. (2007). A mutation in the arabidopsis MAP kinase kinase 9 gene results in enhanced seedling stress tolerance. Plant Science 173: 302-308. DOI: https://doi.org/10.1016/j.plantsci.2007.06.007

Arnon D.I. (1949). Copper enzymes in isolated chloroplasts. Polyphenoloxidase in Beta vulgaris. Plant Physiology 24(1): 1-15. DOI: https://doi.org/10.1104/pp.24.1.1

Bashir M.A. \& Malik B.A. (1988). Disease of major pulse crops in Pakistan. Tropical Pest Management 34: 309-314. DOI: https://doi.org/10.1080/09670878809371262

Bates L.S., Waldren R.P. \& Teare I.D. (1973). Rapid determination of free proline for water stress studies. Plant Soil 39: 205-207. DOI: https://doi.org/10.1007/BF00018060

Beckers G.J.M., Jaskiewicz M., Yidong L.Y., Underwood W.R., He S.Y., Zhang S. \& Conrath U. (2009). Mitogen-activated protein kinases 3 and 6 are required for full priming of stress responses in Arabidopsis thaliana. The Plant Cell 21: 944-953. DOI: https://doi.org/10.1105/tpc.108.062158

Cletus J., Balasubramanian V., Vashisht D. \& Sakthivel N. (2013). Transgenic expression of plant chitinases to enhance disease resistance. Biotechnology Letters 35: 1719-1732. DOI: https://doi.org/10.1007/s10529-013-1269-4
Dubo M., Gilles K., Hamilton J.K., Rebers P.A. \& Smith F. (1956). Colorimetric method for determination of sugars and related substances. Analytical Chemistry 28: 350-356. DOI: https://doi.org/10.1021/ac60111a017

Eastburn D.M., McElrone A.J. \& Bilgin D.D. (2011). Influence of atmospheric and climatic change on plant-pathogen interactions. Plant Pathology 60(1): 54-69.

DOI: https://doi.org/10.1111/j.1365-3059.2010.02402.x

Ebrahim S., Usha K. \& Singh B. (2011). Pathogenesis related (PR) proteins in plant defense mechanism. In: Science Against Microbial Pathogens: Communicating Current Research and Technological Advances (ed. A. MendezVilas), $3^{\text {rd }}$ edition, volume 2, pp. 1043-1054. Formatex Research Centre Publisher, Badajoz, Spain.

El-kereamy A., El-sharkawy I., Ramamoorthy R., Taheri A., Errampalli D., Kumar P. \& Jayasankar S. (2011). Prunus domestica pathogenesis-related protein-5 activates the defense response pathway and enhances the resistance to fungal infection. PLOS-One 6: e17973.

DOI: https://doi.org/10.1371/journal.pone.0017973

Eschen-Lippold L., Bethke G., Palm-Forster M.A.T., Pecher P., Bauer N., Glazebrook J., Scheel D. \& Lee J. (2012). MPK11-a fourth elicitor-responsive mitogen-activated protein kinase in Arabidopsis thaliana. Plant Signal and Behavior 7(9): 1203-1205.

DOI: https://doi.org/10.4161/psb.21323

Grover A. (2012). Plant chitinases: genetic diversity and physiological roles. Critical Reviews in Plant Science 31: 57-63.

DOI: https://doi.org/10.1080/07352689.2011.616043

Hirabayashi J. (1996). On the origin of elementary hexoses. Quarterly Review of Biology 71: 365-380. DOI: https://doi.org/10.1086/419443

Hu X. \& Reddy A.S. (1997). Cloning and expression of a PR5like protein from Arabidopsis: inhibition of fungal growth by bacterially expressed protein. Plant Molecular Biology 34: 949-959. DOI: https://doi.org/10.1023/A:1005893119263

Jayaraj J \& Punja Z.K. (2007). Combined expression of chinitase and lipid transfer protein genes in transgenic carrot plants enhances resistance to foliar fungal pathogens. Plant Cell Replication 26: 1539-1546.

DOI: https://doi.org/10.1007/s00299-007-0368-x

Johnson R.P., Balwani T.L., Johnson L.J., Meclure K.E. \& Denority B.A. (1966). Corn plant maturity II effect on in vitro cellular digestibility and soluble carbohydrate content. Journal of Animal Science 25: 617-623. DOI: https://doi.org/10.2527/jas1966.253617x

Khan S.K. (2007). M. phaseolina as causal agent for charcoal rot of sunflower. Mycopathology 5: 111-118.

Liu B. et al. (11 authors) (2010). Cloning and characterization of a wheat $\beta$-1, 3-glucanase gene induced by the stripe rust pathogen Puccinia striiformis f. sp. tritici. Molecular Biology Reports 37: 1045-1052. DOI: https://doi.org/10.1007/s11033-009-9823-9

Lobato A.K.S., Goncalves-Vidigal M.C., Vidigal Filho P.S., Costa R.C.L., Cruz F.J.R., Santos D.G.S., Silva C.R., Silva L.I. \& Souza L.L. (2009). Changes in photosynthetic pigment and carbohydrate content in common bean 
cultivars infected by Colletotrichum lindemuthianum. Plant Soil Environment 55: 58-61. DOI: https://doi.org/10.17221/259-PSE

Lowry O.H., Rosebrough N.J., Farr A.L. \& Randall R.J. (1951). Protein measurement with the folin phenol reagent. Journal of Biological Chemistry 193: 265-275.

Mayek-Perez N., Lopez-Castaneda C., Lopez-Salinas E., Cumpian-Gutierrez J. \& Acosta-Gallegos J.A. (2001). Macrophomina phaseolina resistance in common bean under field conditions in Mexico. Agrociencia 35: 649-661.

Moravcikova J., Margentinyova D., Galova Z., Zur I., Gregorova Z., Zimova M., Boszoradova E. \& Ildiko M.I. (2016). Beta-1,3-Glucanase activities in wheat an relative species. Nova Biotechnologica et Chimica 15: 122-132. DOI: https://doi.org/10.1515/nbec-2016-0013

Morkunas I. \& Lech Ratajczak L. (2014). The role of sugar signaling in plant defense responses against fungal pathogens. Acta Physiology Plant 36: 1607-1619. DOI: https://doi.org/10.1007/s11738-014-1559-z

Murashige T. \& Skoog F. (1962). A revised medium for rapid growth and bioassays with tobacco tissue cultures. Plant Physiology 15: 473-497.

DOI: https://doi.org/10.1111/j.1399-3054.1962.tb08052.x

Parkhi V., Kumar V., Sunilkumar G., Campbell L.A.M., Singh N.K. \& Rathore K.S. (2009). Expression of apoplastically secreted tobacco osmotin in cotton confers drought tolerance. Molecular Breeding 23: 625-639.

DOI: https://doi.org/10.1007/s11032-009-9261-3

Pathan E.K., Ghormade V. \& Deshpande M.V. (2017). Selection of reference genes for quantitative real-time RTPCR assays in different morphological forms of dimorphic zygomycetous fungus Benjaminiella poitrasii. PLoS ONE 12(6): e0179454.

DOI: https://doi.org/10.1371/journal.pone.0179454

Pazarlar S., Mustafa G.M. \& Golgen O.G.B. (2013). The effects of tobacco mosaic virus infection on growth and physiological parameters in some pepper varieties (Capsicum annum L.). Notulae Botanicae Horti Agrobotanicae 41(2): 427-433.

DOI: https://doi.org/10.15835/nbha4129008

Purkayastha S., Kaur B., Dilbaghi N. \& Chaudhury A. (2006). Characterization of Macrophomina phaseolina, the charcoal rot pathogen of cluster bean, using conventional techniques and PCR-based molecular markers. Plant Pathology 55: 106-116.

DOI: https://doi.org/10.1111/j.1365-3059.2005.01317.x

Qamar A., Mysore K.S. \& Senthil-Kumar M. (2015). Role of proline and pyrroline-5-carboxylate metabolism in plant defense against invading pathogens. Front Plant Science 6: 503-509.

DOI: https://doi.org/10.3389/fpls.2015.00503

Raguchander T., Samiyappan R. \& Arjunan G. (1993). Biocontrol of Macrophomina root rot of mungbean. Indian Phytopathology 46: 379-382.

Roberts W.K. \& Selitrennikoff C.P. (1990). Zeamatin, an antifungal protein from maize with membranepermeabilizing activity. Journal of General Microbiology
136: $1771-1778$.

DOI: https://doi.org/10.1099/00221287-136-9-1771

Scheideler M., Schlaich N.L., Fellenberg K., Beissbarth T., Hauser N.C., Vingron M., Slusarenko A.J. \& Hoheisel D.D. (2002). Monitoring the switch from housekeeping to pathogen defense metabolism in Arabidopsis thaliana using cDNA arrays. Journal of Biological Chemistry 277: 10555-10561.

DOI: https://doi.org/10.1074/jbc.M104863200

Sela-Buurlage M.B., Ponstein A.S., Bres-vloemans S.A., Melchers L.S., Elzen P.J.M. \& Comelissen B.J.C. (1993). Only specific tobacco (Nicotiana tabacum) chitinase and 1, 3-glucanase exhibit antifungal activity. Plant physiology 101: $857-863$.

DOI: https://doi.org/10.1104/pp.101.3.857

Short G.E. \& Wyllie T.D. (1980). Bristow PR: survival of $M$. phaseolina in soil and residue of soybeans. Phytopathology 70: 13-17.

DOI: https://doi.org/10.1094/Phyto-70-13

Singh D., Ambroise A., Haicour R., Sihachakr D. \& Rajam M.V. (2014). Increased resistance to fungal wilts in transgenic eggplant expressing alfalfa glucanase gene. Physiology and Molecular Biology of Plants 20: 143-150.

DOI: https://doi.org/10.1007/s12298-014-0225-7

Sobti A.K. \& Sharma L.C. (1992). Cultural and pathogenic variations in isolates of Rhizoctonia bataticola from groundnut in Rajasthan. Indian Phytopathology 45: $117-119$.

Souza T.P., Dias R.O. \& Silva-Filho M.C. (2017). Defenserelated proteins involved in sugarcane responses to biotic stress. Genetics and Molecular Biology 40: 360-372. DOI: https://doi.org/10.1590/1678-4685-gmb-2016-0057

Su G., Suh S.O., Schneider R.W. \& Russin J.S. (2001). Host specialization in the charcoal rot fungus, Macrophomina phaseolina. Phytopathology 91: 120-126.

DOI: https://doi.org/10.1094/PHYTO.2001.91.2.120

Subramanyam K., Arun M., Mariashibu T.S., Theboral J., Rajesh M., Singh N.K., Manickavasagam M. \& Andy G.A. (2012). Over expression of tobacco osmotin (Tbosm) in soybean conferred resistance to salinity stress and fungal infections. Planta 236: 1909-1925.

DOI: https://doi.org/10.1007/s00425-012-1733-8

Verslues P.E. \& Sharma S. (2010). Proline metabolism and its implications for plant-environment interaction. Arabidopsis Book 8: e0140.

DOI: https://doi.org/10.1199/tab.0140

Whetherley P.E. (1950). Studies in the water relations of the cotton plant. I. The field measurement of water deficits in leaves. New Phytologist 49: 81-97.

DOI: https://doi.org/10.1111/j.1469-8137.1950.tb05146.x

Wrather J.A., Anderson T.R., Arsyad D.M., Tan Y., Ploper L.D., Porta-Puglia A., Ram H.H. \& Yorinori J.T. (2001). Soybean disease loss estimates for the top 10 soybean producing countries in 1998. Canadian Journal of Plant Pathology 23: $115-121$.

DOI: https://doi.org/10.1080/07060660109506918 